\title{
The Effect of Self-Reflection Activities on Preservice Science Teachers' Classroom Teaching Practices
}

\author{
Didem KARAKAYA CİRIT *1 (D) Selçuk AYDEMIR 2 (D) \\ ${ }^{1}$ Munzur University, Çemişgezek Vocational School, Tunceli, Turkey, ddmkrkycrt@gmail.com \\ ${ }^{2}$ Muş Alparslan University, Faculty of Education, Muş, Turkey, s.aydemir@alparslan.edu.tr \\ * Corresponding Author: ddmkrkycrt@gmail.com
}

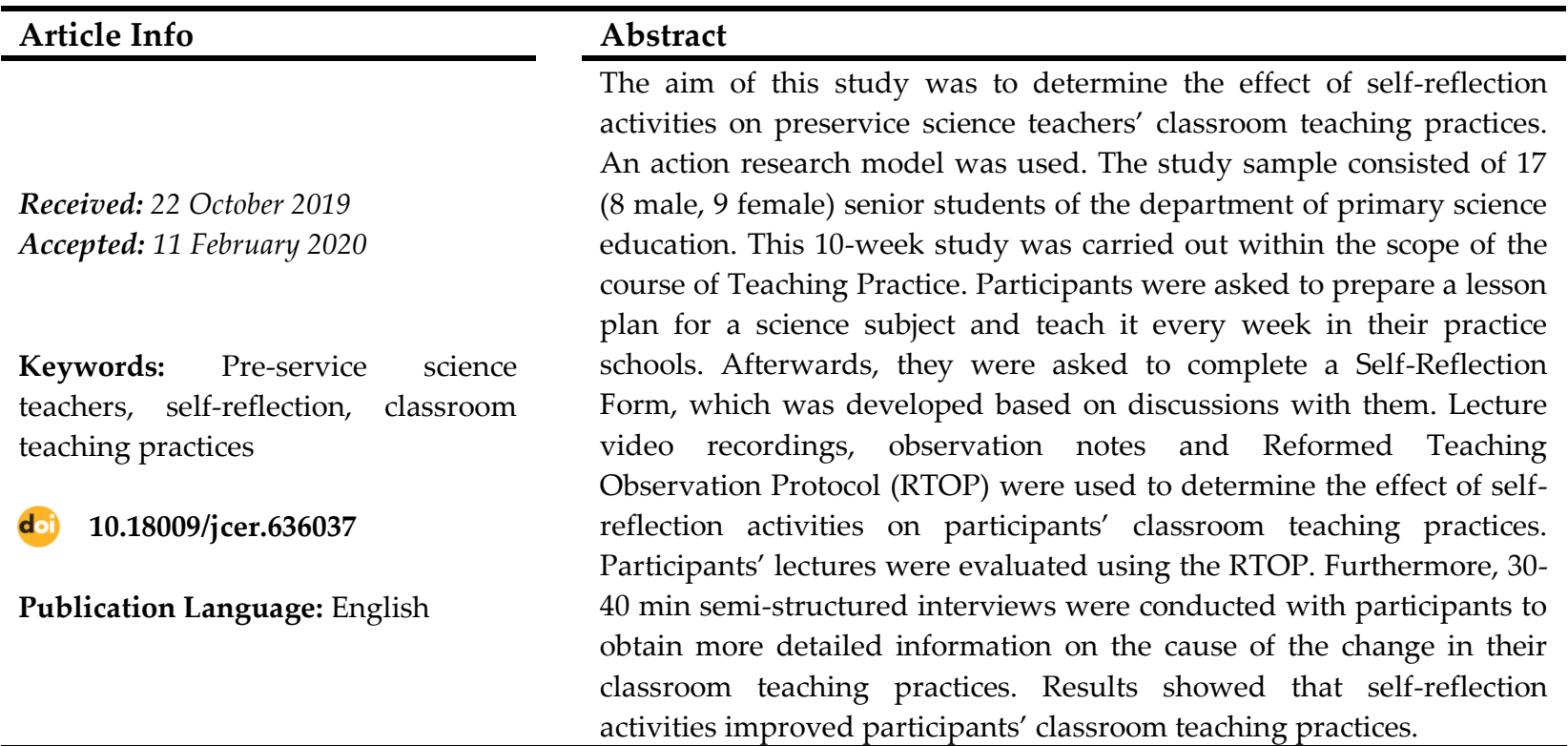
effect of self-reflection activities on preservice science teachers' classroom teaching practices. Journal of Computer and Education Research, 8 (15), 28-40. DOI: 10.18009/jcer.636037

\section{Introduction}

Societies need qualified and competent workforce to advance in a global competitive environment. The most effective way to transform people into qualified individuals is providing them with quality education, which can only be achieved by qualified teachers who can develop effective educational environments and ensure meaningful and permanent learning (Ministry of National Education [MoNE], 2008; Turkish Education Association [TEA], 2009). Since teachers who are in constant interaction with their students play a key role in their academic achievement and quality (Hanuscin, Lee \& Akerson, 2010), there is a significant relationship between teacher quality and student achievement (European Parliament, 2008; TEA, 2009). There have been decades of debate on what kind of knowledge 
that qualified teachers should possess, and Shulman (1986) is the first to develop a model to analyze it. Shulman defines his model as Pedagogical Content Information (PCK) and states that although it consists of content and pedagogical knowledge, it is a different kind of knowledge. In recent years, PCK has been regarded as the most important indicator of qualified teachers, and therefore, is addressed by numerous educational reform documents as a knowledge base that teachers should possess (American Association for the Advancement of Science [AAAS], 1993; National Research Council [NRC], 1996). Researchers have either added new types of knowledge to PCK (Grosman, 1990) or revised the existing knowledge content (Cochran, DeRuiter \& King, 1993). For example, Grossman (1990) expanded Shulman's definition of PCK and added four more areas of knowledge (subject matter knowledge for teaching, knowledge of students' understanding, curricular knowledge and knowledge of instructional strategies). Cochran et al. (1993) renamed PCK as Pedagogical Content Knowing PCK and defined the latter as "a teacher's integrated understanding of four components of pedagogy, subject matter content, student characteristics, and the environmental context of learning" (Cochran, et al., 1993, p. 266). Shulman's model highlights the role of faculties of education in the development of preservice teachers' knowledge of students and environmental context. The articles published in international education journals (Computers and Education, British Journal of Educational Technology) have addressed PCK with reference to technology especially since 2007. Mishra and Koehler (2006) developed a new model, referred to as Technological Pedagogical Content Knowledge (TPCK), based on the integration and interaction of technology, content and pedagogy (Figure 1).

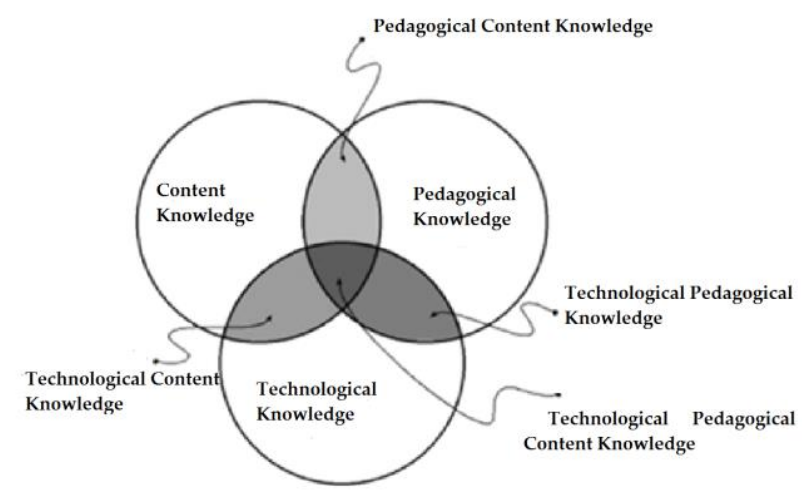

Figure 1. Technological pedagogical content knowledge (TPCK) model (Mishra \& Koehler, 2006) 
Teachers/preservice teachers should first recognize their weaknesses or shortcomings to be able to use their knowledge, skills and experiences in classroom teaching. Elaldı (2015) argues that teachers can assess their own knowledge, skills and behavior and recognize and improve their shortcomings only through self-reflection. Roberts (1998) also argues that the more knowledge, skills and experiences the teachers use in teaching, the more learning occurs. The School Experience (SE) and TP courses offered in undergraduate programs help students develop those skills before they enter professional life. However, there are serious problems in teacher education, the activities in SE and TP courses are not sufficient, and the OE and TP courses fail to reach their goals (Güzel \& Oral, 2008; Karakaya-Cirit, 2017; Karakaya, 2012; Şimşek, 2005). Those courses should, therefore, include self-reflection activities to help preservice teachers to improve their professional competence and to develop positive attitudes towards their profession.

\section{Self-Reflection}

The concept of self-reflection is defined differently by researchers. Von Wright (1992) defines self-reflection as one's ability to observe, interpret and control one's own experiences to improve oneself while Moon (2004) defines it as a process in which one evaluates one's own behavior critically. Kolb (1984), on the other hand, defines it as an analysis of knowledge, skills and experiences to develop for the future. Although the concept of selfreflection is defined differently by different authors, it can be defined as views and thoughts in general. Self-reflection allows one to take responsibility for one's own efforts (course practices, course planning, lecturing etc.) and to follow one's development process and reflect it on oneself. It also raises one's awareness and helps one to understand what one does and why. Self-reflection has two important stages; self-judgment and self-reaction (Zimmerman, 2002). Self-evaluation, which is a form of self-judgment, can be defined as evaluating one's own performance based on certain standards. Self-reaction, defined as adaptive and defensive responses, involves one's positive thoughts about one's performance and feelings of self-satisfaction.

Grenfell (1998) argues that teachers should have a sense of responsibility and the ability to evaluate themselves objectively and critically to be able to self-reflect on their own practice. These characteristics are important for professional development. If teachers lack in 
them, they may have difficulty recognizing and reflecting on their weaknesses or shortcomings in their knowledge and experience.

Self-reflection is investigated by very few studies, which are not even directly related to science education (Elald1, 2015). Further research is warranted in that regard. The aim of this study was, therefore, to determine the effect of self-reflection activities on preservice science teachers' (PSTs) classroom teaching practices. This study sought answers to the following questions:

1. What is the effect of self-reflection activities on PSTs' classroom teaching practices?

1.1. What is the effect of self-reflection activities on PSTs' course design and practice?

1.2. What is the effect of self-reflection activities on PSTs' conceptual knowledge?

1.3. What is the effect of self-reflection activities on PSTs' operational knowledge?

1.4. What is the effect of self-reflection activities on PSTs' interactive communication?

1.5. What is the effect of self-reflection activities on PSTs' teacher-student relationship?

\section{Methodology}

An action research model was used to determine the effect of self-reflection activities on PSTs' classroom teaching practices. "Action research is a process-oriented research model by which a process is addressed for a long time in its own environment and data is collected about it. This allows us to better understand developments and changes in problems and interactions with individuals in the environment" (Yıldırım \& Şimşek, 2016, p. 74).

Study Group

The study sample consisted of 17 (8 male, 9 female) senior students of science teaching department. Criterion sampling was used. "Criterion sampling involves the selection of all cases that meet a predetermined set of criteria" (Yıldırım \& Şimşek, 2016, p. 123). The sampling criterion of this study was that preservice teachers had had no previous experience with any reflection process.

Research Process

This 10-week study was carried out within the scope of the TP. Participants were asked to prepare a lesson plan for a science subject and teach it every week in practice schools. Afterwards, they were asked to complete the Self-Reflection Form, which was developed based on discussions with them. A literature review was conducted to prepare a draft. Afterwards, the structure and relevance of the draft items were discussed with 
participants, and the items were modified or reworded based on their feedback. Science education faculty members were consulted, and the form was finalized based on their feedback. Participants were asked to design lesson plans on science topics every week. Then, the researcher evaluated their lesson plans and gave them feedback addressing shortcomings in information areas such as determination and evaluation of student prior knowledge, methods and techniques, technology integration, and evaluation approaches etc. Participants were asked to design lesson plans again based on feedback and to use them in their science lectures, which were video recorded by the researcher, who also took RTOP and observation notes. Participants were allowed to watch the video recordings of their lectures and saw their own teaching process. Afterwards, they were asked to complete the Self-Reflection Form. This process continued in the same way for 10 weeks with all participants. Figure 2 shows the process. The aim of the self-reflection activity was to determine participants' views of their classroom teaching and determine their level of awareness of the instructional process during their classroom teaching. The aim of the lesson plan was to determine how coherent participants' classroom teaching was, what did not go according to the plan, and why and how much of it they were aware of? The Reformed Teaching Observation Protocol (RTOP) (Piburn et al., 2000) was used to determine the effect of self-reflection activities on participants' classroom teaching practices.

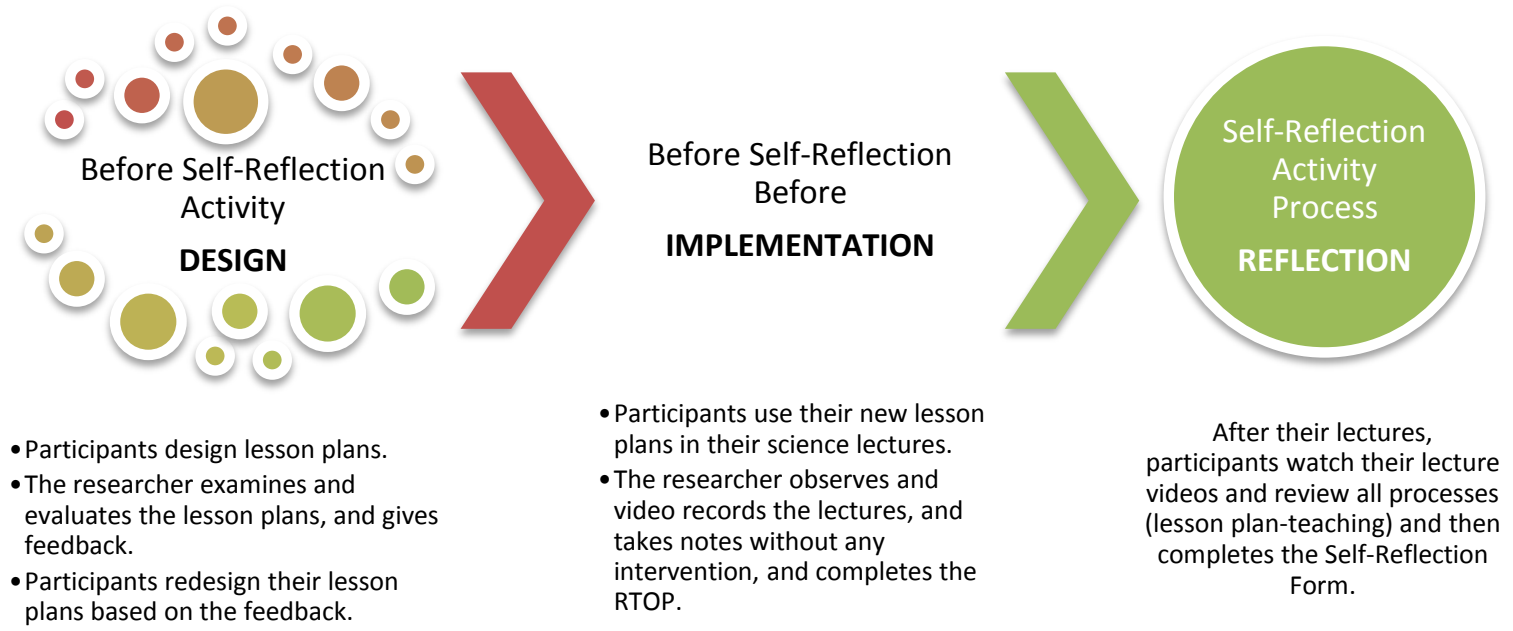

Figure 2. Self-reflection activity steps 


\section{Data Collection Tools}

Lecture video recordings, observation notes and the RTOP were used to determine the effect of self-reflection activities on participants' classroom teaching practices. Moreover, semi-structured interviews were conducted to obtain more detailed data.

\section{Lecture Video Recordings}

Permission was obtained from parents, the school administration, consultant teachers and participants. Participants' lectures were videotaped. Video recordings were used to enable participants to watch themselves teaching and then to complete the self-reflection form. The lectures were video-recorded also because videos can be watched over and over again and can be used to determine nonverbal cues and behaviors. A camera was installed in the classroom in such a way that it did not disrupt the atmosphere and kept participants' faces out of sight.

\section{Observation Notes}

Observation notes were also used to determine participants' classroom teaching practices. The researchers observed participants' classroom teaching and took detailed notes without affecting their performance. The observation notes included information on methods, techniques and activities that participants used during their lectures, their assessment approaches and tools, the structure of teacher-student interaction, their attitudes towards unexpected situations, and integration of technology into learning-teaching and evaluation.

\section{Reformed Teaching Observation Protocol (RTOP)}

The Reformed Teaching Observation Protocol-RTOP developed by Piburn et al. (2000) and adapted to Turkish by Türel (2008) was used to determine participants' classroom teaching practices. The science education literature has different observation protocols such as the classroom observation and analytic protocol (Horizon Research, 2000), and general information configuration model - classroom observation protocol (Ebenezer, Chacko, Kaya, Koya \& Ebenezer, 2010). Some observation protocols focus particularly on a method. The RTOP was developed to determine how often science and mathematics teachers use constructivism in their lectures (Piburn et al., 2000). The RTOP, which was developed in 1998 within the scope of the Arizona Collaborative for Excellence in the Preparation of Teachers 
(ACEPT) project was supported by the National Science Foundation (NSF) as well. The RTOP consists of 5 subscales and 25 items scored on a scale of 0 (not observed) to 4 (very descriptive). Scores range from 0 to 100 points.

\section{Semi-Structured Interviews}

Thirty- to forty -minute semi-structured interviews were conducted with participants to determine the cause of the change in their classroom teaching practices and to obtain more detailed data. The interview questions were based on literature review and expert feedback. Some of the questions were as follows: Do you think that self-reflection activities have an effect on the design and implementation of science lectures? Why? Do you think that selfreflection activities contribute to interaction with students in science lectures? Explain why or why not, please. The interviews were audio-recorded and transcribed and then analyzed.

\section{Data Analysis}

The lecture observation notes and video recordings were holistically used to complete the RTOP for participants. The researchers first took observation notes and then completed the RTOP during participants' classroom teaching. The researchers reviewed the video recordings and observation notes one month after the study and completed the RTOP again. The discrepancies between the first and second observation protocols were corrected based on the feedback of another expert researcher. After the RTOP data was finalized, the means and standard deviations of the RTOP subscale data were analyzed for each week. The interview data were analyzed using content analysis.

\section{Findings}

All data were holistically analyzed. The data showed that participants' classroom teaching practices improved.

1. What is the effect of self-reflection activities on PSTs' classroom teaching practices?

\subsection{What is the effect of self-reflection activities on PSTs' course design and practice?}

All participants made progress in the "course design and implementation" stage of the RTOP over the weeks. For example, their first, fifth and tenth-week success rates were $43.52 \%, 48.23 \%$ and $60.29 \%$, respectively (Table 1). In the first weeks, participants had difficulty designing their lessons in a way that would encourage student engagement. Instead, they designed conventional lessons in which students remained passive. Over the 
weeks, participants designed their lessons in a way that would encourage active student engagement and associate them with their pre-learning. Following is an excerpt from an interview:

...Actually, I know exactly how to design lessons, but in practice it just doesn't work the way I want... I mean... I just can't put what I have in mind into practice. At first, I was afraid that I would turn out a bad teacher...I kept asking 'How am I going to pull this off?'... But, I have realized where I am thanks to the self-reflection activities...Well...I've found answers to the questions like 'Where am I as a teacher? What am I missing in my lesson designs? What can I do better?... (PST-17).

\subsection{What is the effect of self-reflection activities on PSTs' conceptual knowledge?}

All participants made progress in the "conceptual knowledge" stage of the RTOP over the weeks. They had similar scores only in the eighth and ninth weeks. Their first-, fifth- and tenth-week success rates were $42.64 \%, 51.76 \%$ and $58.82 \%$, respectively (Table 1 ). Concerning the "conceptual knowledge" stage, participants had gaps in their knowledge of basic concepts and addressed them superficially in the first weeks. Towards the last weeks, they discussed the basic concepts more comprehensively and even established connections between those concepts and other disciplines and made sure that the lessons promoted meaningful and permanent learning. The interviews also support these results. Following is an excerpt from an interview:

Which concepts should be addressed during the lesson? At what stage of the lesson should they be addressed?...Well...I mean...I just can't do that...I wonder whether the students learn them, or how do they learn them? Such questions gnawed away at my mind... I found answers to these questions by watching myself. For example, I did self-reflection, and in this way, I had a chance to see which concepts I addressed and which ones I skipped or I've realized that I can assess whether students have learned meaningfully or not. It's helped me a lot. It's worked like a mirror and allowed me to see myself and my shortcomings (PST-12).

1.3. What is the effect of self-reflection activities on PSTs' operational knowledge?

All participants made progress in the "operational knowledge" stage of the RTOP over the weeks. They had similar scores only in the first and second weeks and in the fifth and sixth weeks (Table 1). Their first-, fifth- and tenth-week success rates were $42.94 \%, 47.35 \%$ and $57.05 \%$, respectively (Table 1 ). In the first weeks, participants had difficulty choosing tools and materials that they could use to test students' predictions or assumptions and creating learning environments that would encourage students to present critical ideas. They also had difficulty engaging students in critical thinking and questioning activities. However, they were more and more successful towards the last weeks. They also mentioned this in their interviews. Following is an excerpt from an interview: 
I think that it is pretty hard to achieve student engagement... I mean...Well... It is a particularly challenging process to organize activities to encourage students to think or question critically or to engage them in those activities!!! Actually...I don't know if it was the process that was hard or was it just me that made a big deal out of it. I can tell you that I can do it more easily now. For example, I can provide students with the opportunity to show what they have learned, at least that's what I think. Because...well... I think that one can succeed as one thinks about it and goes over it, that is, if one constantly updates oneself. I think I've pulled this off with reflection papers (PST-10).

1.4. What is the effect of self-reflection activities on PSTs' interactive communication?

All participants made progress in the "interactive communication" stage of the RTOP over the weeks. They had similar scores only in the third and fourth weeks and in the eighth and ninth weeks. They had a success rate of $44.41 \%$, around $47 \%$, around $57 \%$ and $60.58 \%$ in the first, third/fourth, eighth/ninth and tenth weeks, respectively (Table 1). All participants had a moderate success in promoting student participation, adjusting the course of the lesson based on students' responses and providing an interactive environment that encouraged student engagement in the first weeks. They, however, managed the process better in the last weeks. Following is an excerpt from an interview:

I don't know how to answer that...Well...Hmm...I think I will love being a teacher because I love children a lot...It is pretty hard to promote student engagement, take their ideas into account and change the course of the lesson based on their ideas...I don't know if I'm capable of that but at least I think about it a lot...You know the papers (self-reflection activity) that you gave us, they've helped me a little bit. If you ask why...I would like to think about it... Well...I compare my performances in my lessons and notice my gap!!!! So, they've been effective although it took some time (PST-3).

\subsection{What is the effect of self-reflection activities on PSTs' teacher-student relationship?}

All participants made progress in the "teacher-student relationship" stage of the RTOP over the weeks. They, however, had similar scores in some weeks (ninth and tenth) (Table 1). Their first-, fifth- and tenth-week success rates were $49.71 \%, 58.23 \%$ and $68.82 \%$, respectively. Participants did not have much difficulty at the "teacher-student relationship" stage. They encouraged students and provided them with an effective learning environment and achieved student engagement. The interviews confirm these results. Following is an excerpt from an interview:

Students...Teaching takes patience...If you have no patience, then you should not be a teacher. But...achieving student engagement is as hard as teaching itself...For example... What to do if the student doesn't want to engage? You have to be patient to get it over with... What to do in such situations? To be honest, at first I faltered but then that self-reflection activity that we did every week was a red alarm for me! It was like saying to me 'Look, you're not good enough, improve yourself!'... Well... Answering these questions and watching myself have improved me over time, I feel it because I can solve this problem in the classroom... (PST-11). 
Table 1. Preservice science teachers' classroom teaching results

\begin{tabular}{|c|c|c|c|c|c|c|c|c|c|c|c|c|c|c|c|c|c|}
\hline \multicolumn{18}{|c|}{ Reformed Teaching Observation Protocol (RTOP) } \\
\hline \multicolumn{3}{|c|}{$\begin{array}{l}\text { Course Design and } \\
\text { Implementation }\end{array}$} & \multicolumn{3}{|c|}{ Conceptual Knowledge } & \multicolumn{3}{|c|}{$\begin{array}{l}\text { Operational } \\
\text { Knowledge }\end{array}$} & \multicolumn{3}{|c|}{ Interactive Communication } & \multicolumn{2}{|c|}{$\begin{array}{l}\text { Teacher-Student } \\
\text { Relationship }\end{array}$} & \multicolumn{4}{|c|}{ Total } \\
\hline $\mathrm{x}$ & sd & $\%$ & $\mathrm{x}$ & sd & $\%$ & $\mathrm{x}$ & sd & $\%$ & $\mathrm{X}$ & sd & $\%$ & $\mathrm{x}$ & sd & $\%$ & $\mathrm{X}$ & sd & $\%$ \\
\hline 8.70 & 2.59 & 43.52 & 8.52 & 1.37 & 42.64 & 8.58 & 2.69 & 42.94 & 8.88 & 2.64 & 44.41 & 9.94 & 3.30 & 49.71 & 8.92 & 2.51 & 44.64 \\
\hline 8.94 & 1.78 & 44.70 & 9.05 & 1.34 & 45.29 & 8.52 & 2.32 & 42.64 & 9.29 & 2.66 & 46.47 & 10.17 & 2.72 & 50.88 & 9.19 & 2.16 & $\% 6.00$ \\
\hline 9.17 & 1.87 & 45.88 & 9.76 & 1.71 & 48.82 & 9.17 & 2.18 & 45.88 & 9.52 & 2.80 & 47.64 & 10.76 & 2.90 & 53.82 & 9.67 & 2.29 & 48.41 \\
\hline 9.58 & 1.73 & 47.94 & 10.05 & 1.85 & 50.29 & 9.23 & 1.98 & 46.17 & 9.58 & 2.95 & 47.94 & 10.94 & 1.71 & 54,70 & 9.87 & 2.04 & 48.09 \\
\hline 9.70 & 1.86 & 48.23 & 10.35 & 1.86 & 51.76 & 9.47 & 1.66 & 47.35 & 10.05 & 2.35 & 50.29 & 11.64 & 1.86 & 58.23 & 10.24 & 1.91 & 51.17 \\
\hline 10.35 & 2.80 & 51.76 & 10.94 & 1.67 & 54.70 & 9.41 & 1.87 & 47.05 & 10.70 & 2.28 & 53.52 & 12.23 & 2.51 & 61.17 & 10.72 & 2.22 & 53.64 \\
\hline 10.52 & 2.50 & 52.64 & 11.17 & 2.24 & 55.88 & 10.35 & 1.93 & 51.76 & 11.11 & 2.23 & 55.58 & 13.05 & 0.82 & 65.29 & 11.24 & 1.94 & 56.23 \\
\hline 11.29 & 1.99 & 56.47 & 11.58 & 1.73 & 57.94 & 10.82 & 2.09 & 54.11 & 11.41 & 2.80 & 57.05 & 13.47 & 2.09 & 67.35 & 11.714 & 2.14 & 58.58 \\
\hline 11.52 & 2.47 & 57.64 & 11.41 & 1.69 & 57.05 & 11.35 & 2.02 & 56.76 & 11.47 & 2.32 & 57.35 & 13.64 & 1.83 & 68.23 & 11.87 & 2.06 & 59.41 \\
\hline 12.05 & 2.70 & 60.29 & 11.76 & 2.43 & 58.82 & 11.41 & 2.18 & 57.05 & 12.11 & 2.64 & 60.58 & 13.76 & 1.34 & 68.82 & 12.21 & 2.25 & 61.11 \\
\hline
\end{tabular}

Participants' first, fifth and tenth-week success rates in the "course design and implementation" stage were $44.64 \%, 51.17 \%$ and $61.11 \%$, respectively (Table 1 ).

\section{Discussion and Conclusions}

The results showed that self-reflection activities improved participants' classroom teaching practices. Participants prepared lesson plans each week prior to their lectures and received feedback from the researcher. They revised their lesson plans based on the feedback of the researcher and used them in their lectures. Afterwards, they watched the video records of their lectures to analyze their own performance. This can explain the improvement in their classroom teaching practices. Thorpe and Barsky (2001) define selfreflection as a process in which one recognizes and analyzes one's current situation in one's life, develops a new perspective, and takes action for change. Preservice teachers may miss important parts of their teaching processes due to the chaos in their classrooms and their responsibility for classroom management. However, watching the video recordings of their lectures can provide them with the opportunity to notice those important points. They can fast forward and rewind their lecture videos and watch them over and over again, which contributes to the development of their classroom teaching (Sherin, 2004). One reason is that participants completed self-reflection activities after classroom teaching every week. The interviews also confirm this. They made the most progress in the "teacher-student relationship" stage, followed by the "course design and implementation" and "interactive communication" stages. Yiğit, Alev and Ekiz (2010) conducted a study of 12 preservice 
teachers to investigate the effect of reflection-based guidance in classroom teaching on their professional development using an observation chart, written feedback on the observation chart, and open-ended questions. They found significant improvements in the preservice teachers' experiences. Concerning the "course design and implementation" stage, participants had difficulty designing lessons in the first weeks but made progress towards the last weeks. Sim (2006) defines self-reflection as a planning tool that develops professional skills and an activity that allows teachers to evaluate their own teaching process and to make changes to teaching methods. Participants had similar conceptual knowledge and interactive communication scores in the first weeks. However, their conceptual knowledge scores slightly increased towards the last weeks. In the first weeks, although participants focused on the subjects and achievements in which they felt more competent (Karakaya-Cirit, 2017; Karakaya-Cirit \& Canpolat, 2019), they tried to focus on all subjects, concepts and achievements towards the last weeks. Self-reflection activities improved the interaction between participants' knowledge structures. Shuell (1990) argues that connections and interactions between knowledge structures play a key role in the transition from inexperience to experience for teachers. The SE and TP undergraduate courses offered by the faculties of education provide preservice teachers with the opportunity to develop classroom teaching practices (Güzel \& Oral, 2008). Those courses help them develop professionally, put theory into practice and develop positive attitudes towards their profession (Güzel \& Oral, 2008). Therefore, the effective execution of self-reflection activities enables teachers to achieve the goals of the SE and TP courses. It is, therefore, recommended that future studies address the self-reflection activities in other departments to help preservice students to develop classroom teaching practices and positive attitudes towards their profession.

Acknowledgement

The data used in this study was confirmed by the researchers that it belongs to the years before 2020.

Authorship Contribution Statement

Didem KARAKAYA CIRIT: Conceptualization, Methodology, Supervision, Formal analysis, Writing - original draft, writing - review E editing.

Selçuk AYDEMİ: Conceptualization, Methodology, Writing - original draft, Writing review E editing. 


\section{References}

American Association for the Advancement of Science [AAAS]. (1993). Benchmarks for science literacy. New York: Oxford University Press.

Cochran, K.F., Deruiter, J.A. \& King, R.A. (1993). Pedagogical content knowing: An integrative model for teacher preparation. Journal of Teacher Education, 44, 263-272.

Ebenezer, J., Chacko, S., Kaya, O. N., Koya, S. K., \& Ebenezer, D. L. (2010). The effects of common knowledge construction model sequence of lessons on science achievement and relational conceptual change. Journal of Research in Science Teaching, 47, 25-46.

Elaldı, Ş. (2015). Öz-yansıtma kavramına genel bakış [An overview on the concept of selfreflection]. Turkish Studies, 10(7), 381-394.

European Parliament, (2008). European Parliament resolution of 23 September 2008 on improving quality of teacher education, (2008/2068(INI)).

Grenfell, M. (1998). Training teachers in practice. Clevedon, UK: Multilingual Matters.

Grossman, P. L. (1990). The making of a teacher: Teacher knowledge and teacher education. New York: Teachers College Press.

Güzel, H., \& Oral, İ. (2008). S. Ü. Eğitim fakültesi OFMAE bölümü öğrencilerinin okul deneyimi etkinlikleri üzerine bir araştırma [A study on school experience activities of OFMAE students of S. U. Faculty of Education]. Selçuk Üniversitesi Ahmet Keleşoğlu Eğitim Fakültesi Dergisi, 25, 249-261.

Hanuscin, D. L., Lee, M. H., \& Akerson, V. L. (2010). Elementary teachers' pedagogical content knowledge for teaching the nature of science. Science and Education, 95(1), 145167.

Horizon Research Inc. (2000). Inside the classroom observation and analytic protocol.

Retrieved 20 June 2013 from http://www.horizonresearch.com/instruments/clas/cop.php.

Karakaya, D. (2012). Fen bilgisi öğretmen adaylarının küresel boyuttaki çevresel sorunlara ilişkin teknolojik pedagojik alan bilgisi ve sınıf içi uygulamalarının araştırılması. (Yayımlanmamış yüksek lisans tezi) [Exploring the pre-service science and technology teachers' technological pedagogical content knowledge and classroom teaching involving the topic of global environmental problems]. Firat Üniversitesi, Eğitim Bilimleri Enstitüsü, Elazığ.

Karakaya-Cirit, D. (2017). Fen bilgisi öğretmen adaylarının pedagojik alan bilgisi ve sınıf içi ögrretimlerinin araştırılması [Exploring the pre-service science teachers' pedagogical content knowledge and classroom teaching practices]. The Journal of Academic Social Science Studies, 63(Winter II), 51-68.

Karakaya-Cirit, D. \& Canpolat, E. (2019). A study on the technological pedagogical contextual knowledge of science teacher candidates across different years of study. Education and Information Technologies, 24 (4), 1-27.

Kolb, D. (1984). Experiential learning: Experience as the source of learning and development. New Jersey: Prentice Hall.

Mishra, P. \& Koehler, M.J. (2006). Technological pedagogical content knowledge: A framework for teacher knowledge. Teachers College Record, 108 (6), 1017-1054. 
Moon, J. A. (2004). A handbook of reflective and experiential learning: Theory and practice. London: Routledge Farmer.

National Research Council [NRC]. (1996). National science education standards. Washington, DC: National Academy Press

Ministry of National Education [MoNE]. (2008). Öğretmen yeterlikleri: Öğretmenlik mesleği genel ve özel alan yeterlikleri [Teacher competencies: General and special field competencies of teaching profession]. Ankara: Devlet Kitapları Müdürlüğü.

Piburn, M., Sawada, D., Turley, J., Falconer, K., Benford, R., Bloom, I., \& Judson, E. (2000). Reformed teaching observation protocol (RTOP) reference manual. Tempe, Arizona: Arizona Collaborative for Excellence in the Preparation of Teachers.

Roberts, J. (1998). Language teacher education. London: Arnold.

Shuell, T.J. (1990). Phases of meaningful learning. Review of Educational Research, 60, 531-547.

Shulman, L. S. (1986). Those who understand: Knowledge growth in teaching. Educational Researcher, 15 (2), 4-14.

Sherin, M. G. (2004). New perspectives on the role of video in teacher education. In J. Brophy (Ed.), Using video in teacher education (pp. 1-28). Amsterdam, Netherlands: Elsevier

Sim, C. (2006). Preparing for professional experiences - incorporating pre-service teachers as 'communities of practice'. Teaching and teacher education, 22(1), 77-83.

Şimşek, H. (2005). Eğitimde reform ve değişim kararlılı̆̆ı. "eğitim fakültelerinde yeniden yapilanmanın getirdiği sorunlar" [Reform and change commitment in education. "the problems of restructuring in education faculties"] paneli, Gazi Üniversitesi, Ankara.

Thorpe, K., \& Barsky, J. (2001). Healing through self-reflection. Journal of Advanced Nursing, 35(5), 760-768.

Türel, Y. (2008). Öğrenme nesneleri ile zenginleştirilmiş öğretim ortamlarının öğrenci başarıları tutumları ve motivasyonlart üzerindeki etkisi. [The effect of the learning objects enriched instructional environments on learners' achievements learners' attitudes and learners' motivations]. (Yayımlanmamış Doktora Tezi), Frrat Üniversitesi, Sosyal Bilimler Enstitüsü. Elazı̆g.

Turkish Education Association [TEA].(2009). Öğretmen yeterlikleri [Teacher Competencies.]. Retrieved November 23, 2011 http://portal.ted.org.tr/yayinlar/Ogretmen Yeterlik Kitap.pdf Von Wright, J. (1992). Reflections on reflection. Learning and instruction, 2(1), 59-68.

Yıldırım, A., \& Şimşek, H. (2016). Sosyal bilimlerde nitel araştırma yöntemleri (10. Baskı) [Qualitative research methods in the social sciences ]. Ankara: Seçkin Yayıncılık

Yiğit, N., Alev, N., \& Ekiz, D. (2010). The contribution of reflective-based mentoring to the initial professional development of student teachers during teaching practice. Inonu University Journal of the Faculty of Education, 11(3), 75-100.

Zimmerman, B. J. (2002). Becoming a self-regulated learner: An overview. Theory into practice, 41(2), 64-70.

JCER's Publication Ethics and Publication Malpractice Statement are based, in large part, on the guidelines and standards developed by the Committee on Publication Ethics (COPE). This article is available under Creative Commons CC-BY 4.0 license (https://creativecommons.org/licenses/by/4.0/) 